\title{
FUNDAMENTAL BASIS FOR THE CONSERVATION OF BIODIVERSITY OF THE BLACK SEA-KAZAKH STEPPES
}

\author{
Olga DEMINA ${ }^{1, *} \&$ Tatiana BRAGINA ${ }^{1,2}$
}

\begin{abstract}
The paper presents new approaches for assessing the conservation value of plant communities based on the use of quantitative criteria contained in databases and eco-floristic classification of steppe vegetation in the Don basin (Rostov region). The Black Sea and Kazakhstan steppes have significant potential for environmental protection. Analysis of biodiversity levels has been facilitated by descriptions of plant communities and quantitative indicators of major faunal groups of soil invertebrates (macrofauna) in the Tobol-Turgai basin (Kostanay region, Kazakhstan). As the structure of soil invertebrate communities is closely associated with vegetation, its assessment can provide insight into the degree of preservation or the depth of disturbance of ecosystems such as those found in the Black Sea and Kazakhstan steppes.

Key words: ecological network, Festucetea vaginatae, Festuco-Brometea, Festuco-Puccinellietea, Helianthemo-Thymetea, phytocenotic diversity, plant community, soil macrofauna.

\section{Izvleček}

V članku so predstavljeni novi pristopi ocenjevanja naravovarstvene vrednosti rastlinskih združb, ki temeljijo na kvantitativnih kriterijih na podlagi podatkovnih baz in ekološko floristične klasifikacije vegetacije porečja reke Don (regija Rostov). Črnomorske in kazahstanske stepe imajo velik potencial za ohranjanje. Analizo biodiverzitete smo podkrepili z opisi rastlinskih združb in kvantitativnimi indikatorji glavnih skupin talnih nevretenčarjev (makrofavna) v porečju Tobol-Turgai (regija Kostanay, Kazahstan). Struktura združb talnih nevretenčarjev je močno povezana z vegetacijo, zato lahko njena ocena omogoča vpogled v stopnjo ohranjenosti oziroma motenosti ekosistemov, ki jih najdemo v stepah ob Črnem morju in v Kazahstanu.

Ključne besede: ekološka mreža, Festucetea vaginatae, Festuco-Brometea, Festuco-Puccinellietea, Helianthemo-Thy-metea, fitocenološka diverziteta, rastlinska združba, talna makrofavna.
\end{abstract}

\section{INTRODUCTION}

A strategic aim of steppe biodiversity conservation is to establish ecological networks with functional integrity for the remnants of natural vegetation in the critically fragmented steppe landscapes (Anon. 2006, Demina 2007). However, identifying the structural elements of the ecological network through the presence of indicators (species and habitats with high conservation value) is not possible without the classification of plant communities. Classification based on ecological and floristic criteria allows for thorough assessment of phytocenotic diversity of the region as well as identification of "objects" by the presence of indicators - i.e. species and natural habitats (Andreev 2002). This approach was used in the evaluation of natural habitats by European phytocenologists in a large phytosociological review (Rodwell et al. 2002, Lysenko et al. 2011). New approaches for assessing the environmental significance of plant communities, based on a consistent aggregation of quantitative criteria contained in documented classifications and databases, have great potential in the field of nature protection and environmental monitoring (Berg et al. in press).

\footnotetext{
${ }^{1}$ Southern Federal University, B. Sadovaya 105, Rostov-on-Don, Russia

${ }^{2}$ Kostanaysky State Pedagogical Institute, Taran 118, Kostanay, Kazakhstan; E-mail: naurzum@mail.ru

* Corresponding author: ondemina@yandex.ru
} 
In the Black Sea-Kazakh sub-region of the Eurasian steppe region, there are two steppe provinces: steppes of the Black Sea area and the TransVolga-Kazakh steppes. Their boundaries are in the Southeast of the Rostov region (Russia). The main objective of this paper is to define the syntaxonomy of this region's steppe vegetation and to assess the environmental significance of plant communities. Plant species' diversity and composition often affect soil biodiversity and biological activity, and soil macrofauna has been shown to be a sensitive indicator of alterations in plant cover (Lavelle \& Pashanasi 1989, De Deyn et al. 2011) and also to have a considerable impact on soil processes (Velásqueza et al. 2012). We therefore take into account the structure of soil in our analysis of the value of community environments.

\section{METHODS}

Selection criteria for the environmental significance of plant communities are important tools, which highlight key areas of the ecological network. Basic principles for the selection of plant communities for protection were formulated by E. M. Lavrenko in three categories: 1. Community edificators, which are rare species, 2 . Communities at the edge of areas and 3. Communities destroyed on a large part of the range (Lavrenko 1971). Ukrainian and Russian botanists subsequently further developed these principles in the form of the Green Book of Ukrainian SSR (ShelyakSosonko 1987), the Green Book of Siberia (Siberian Academy of Sciences 1996) and others (Stojko et al. 1996, Martynenko \& Mirkin 2006).

The system assessment to determine the most valuable habitats in Europe has been developed within the framework of the programs of international conservation organizations (WWF, IUCN) including the Global Strategy for Plant Conservation, Important Plant Areas (IPA) and the PanEuropean Biological and Landscape Diversity. Recent classification of the priorities of habitat protection in Europe was directly related to the assessment of plant communities (Riecken et al. 2006). A major review of European vegetation mapping was recently performed using a phytosociological approach (Braun-Blanquet 1964).

Herein, syntaxonomical units were related to EUNIS natural habitats (Rodwell et al. 2002).

We used an eco-floristic classification to describe the vegetation communities in this region.
Genuine forb-bunchgrass, bunchgrass steppes and desertified semi-shrub and bunchgrass steppes were related to the class Festuco-Brometea Br.Bl. et Tx. 1943. Petrophytic vegetation was related to the class Helianthemo-Thymetea Romashchenko, Didukh et Solomakha 1996. Psammophyte communities were related to the class Festucetea vaginatae Soó em. Vicherek 1972, and halophyte vegetation of alkali or solonetz soils and hemihalophyte derivative communities were related to the class Festuco-Puccinellietalia Soó ex Vicherek 1973 (Lysenko et al. 2011). In total, our research defined 37 plant associations in six alliances, four orders and four classes, giving an eco-floristic classification of the plant communities that are present in the Black Sea-Kazakh steppe of the Don basin (Demina 2011, 2012).

Next, we combined this classification, based on the comparison of typological and syntaxonomic vegetation units, with data on the phytocenotic diversity of the species of the cenoflora (Table 1). These quantitative data provide a measure of species richness in this community and its cenose-forming role.

New approaches to the assessment of environmental relevance of phytodiversity and plant communities, based on a consistent aggregation of quantitative criteria contained in documented vegetation classifications and databases, have great potential in the field of nature protection and environmental monitoring (Berg et al. in press). The eco-floristic classification of vegetation steppes of the Don basin (Russia) was based on representative quantitative data (Demina 2011) in the form of numerous relevés (1116 descriptions of small plots of vegetation).

Expert assessments were conducted to identify plant communities at risk for poor conservation. Five independent basic criteria were used: A criterion to identify key plant areas (IUCN), the types of natural habitats (EUNIS), rarity, protection measures and floristic-phytocenotic significance.

\subsection{CRITERIA FOR CONSERVATION IMPORTANCE OF PLANT COMMUNITIES}

Criterion $\mathrm{A}$ - this is the first of three criteria recommended by Planta Europa for IPA identification (Anderson 2003). We propose another category A (v) for the species listed in the Red Book of the Russian Federation (Anon. 2008) and the Red Book of the Rostov Region (Anon. 2004). This new category postulates specific criteria for IPA 
Table 1: Typological and syntaxonomic categories of steppe vegetation. Rostov region (Russia).

Tabela 1: Tipološke in sintaksonomske kategorije stepske vegetacije, regija Rostov (Rusija).

\begin{tabular}{|c|c|}
\hline Type (flora-cenotype) & Class \\
\hline Regional typological categories and variants & Associations \\
\hline STEPPES (Xeropojon eurasiaticum, Steppae) & Festuco-Brometea Br.-Bl. et Tx. 1943 \\
\hline $\begin{array}{l}\text { Eastern Black Sea rich forb-bunchgrass steppes, pelitophytic } \\
\text { and hemipsammophytic }\end{array}$ & $\begin{array}{l}\text { Trifolio alpestris-Stipetum tirsae, Bellevaliae sarmaticae- } \\
\text { Stipetum pennatae, Stipetum pennatae }\end{array}$ \\
\hline $\begin{array}{l}\text { West-Black Sea rich forb-bunchgrass steppes, pelitophytic } \\
\text { and hemipetrophytic }\end{array}$ & $\begin{array}{l}\text { Centaureo orientalii-Stipetum pulcherrimae, } \\
\text { Plantagini stepposae-Stipetum pulcherrimae }\end{array}$ \\
\hline Eastern Black Sea forb-bunchgrass steppes, pelitophytic & $\begin{array}{l}\text { Eryngio campestris-Stipetum ucrainicae, Sileno wolgensis- } \\
\text { Stipetum pulcherrimae }\end{array}$ \\
\hline West-Black Sea forb-bunchgrass steppes, pelitophytic & $\begin{array}{l}\text { Eryngio campestris-Stipetum ucrainicae, Ajugo orientalis- } \\
\text { Festucetum pseudovinae, Medicago romanicae-Stipetum } \\
\text { ucrainicae, Astragalo ponticae-Dianthetum leptopetali, } \\
\text { Stipetum lessingianae }\end{array}$ \\
\hline Black Sea forb-bunchgrass steppes, pelitophytic & $\begin{array}{l}\text { Medicago romanicae-Festucetum valesiacae, Astragalo } \\
\text { albicaulis-Stipetum capillatae, Elytrigio trichophorae- } \\
\text { Festucetum rupicolae, Euphorbio seguieranae-Thymetum } \\
\text { dimorphi, Convolvulis lineati-Vincetoxietum maeotici, } \\
\text { Genisto scythicae-Stipetum adoxae }\end{array}$ \\
\hline Black Sea forb-bunchgrass steppes, hemipsammophytic & Stipetum capillatae, Festuco rupicolae-Stipetum dasyphyllae \\
\hline Eastern Black Sea bunchgrass steppes, pelitophytic & Medicago romanicae-Festucetum valesiacae \\
\hline Trans-Volga-Kazakhstan bunchgrass steppes, pelitophytic & Astragalo asperi-Medicagetum romanicae \\
\hline $\begin{array}{l}\text { Black Sea-West Caspian Sea semishrub-bunchgrass steppes, } \\
\text { hemihalophytic }\end{array}$ & $\begin{array}{l}\text { Amorio retusae-Cerastietum syvaschici, } \\
\text { Agropyrini pectinati-Poetum bulbosae }\end{array}$ \\
\hline $\begin{array}{l}\text { Ast Black Sea-West Caspian Sea semishrub-bunchgrass } \\
\text { steppes, hemihalophytic }\end{array}$ & Artemisio lerchianae-Poetum bulbosae \\
\hline
\end{tabular}

\section{PSAMMOPHYTIC VEGETATION \\ (Psammophyton)}

Festucetea vaginatae Soo em. Vicherek 1972

Secalo-Stipetum borysthenicae, Hieracio echioidis-Stipetum borysthenicae, Scirpoido-

Genistaetum sibiricae

Artemisio arenariae-Festucetum beckeri,

Centaureo gerberi-Agropyretum tanaitici
PETROPHYTIC VEGETATION

(Petrophyton)

\section{Helianthemo-Thymetea Romashchenko, Didukh et Solomakha 1996 \\ Matthiolo fragransi-Atraphaxietum frutescens, Hedysaro cretacei-Melicetum transsilvanicae, Lepidio meyeri-Scrophularietum cretacei, Sileno borysthenicae-Hyssopetum angustifolii, Erysimo cretacei-Festucetum cretacei, Genisto scythicae- Artemisietum salsoloidis, Artemisio hololeucae- Polygaletum cretaceae}


identification in the Russian Federation and Rostov region to prioritize areas as core features of an ecological network. As some species proposals for regional Red Lists may be inadequate, we also invoked the list of Appendix 10 of the Bern Convention (Standing Committee to the Bern Convention 2011). EUNIS habitat types are considered in accordance with the classification of habitat conservation priority in Europe following the Emerald Book of the Russian Federation (Institute of Geography of RAS 2013).

The rarity index $(\mathrm{R})$ describes plant community occurrence depending on size and frequency. Rarity is estimated according to the species rarity scale (Rabinowitz et al. 1986), which was later adapted for plant communities (Izco 1998).

The nature protection measures index $(\mathrm{N})$ estimates the share of communities of the total diversity array that are inside nature protection areas. This category implies that a community is best protected from threats if it is inside such a protected area. Protection levels were measured as the proportion of communities across the spectrum of diversity to maintain for which the necessary measures have already been taken: N0 - not protected, N1 - protected by at least $20 \%$, N2 protected by $21 \%$ to $50 \%$, N3 - protected by $51 \%$ to $70 \%, \mathrm{~N} 4$ - protected by more than $70 \%$.

The floristic-phytocenological value (F) is an aggregate index of conservation priority.

In addition to evaluating the environmental significance of plant communities in the allocation of key areas as econet priorities for the protection of habitats, there is also an important role of assessing the level of zoological diversity in general. This paper focuses on composition and abundance of soil invertebrate communities of the sub-zones of the Kazakh steppes (macrofauna) in the Kostanay region. A standard soilzoological sampling method (Gilyarov 1965) was used to investigate the composition and abundance of soil invertebrates in the main sub-zonal steppes. For at least two years, assessments were made in each stationary site in different steppe sub-zones. Specifically, soil samples were acquired through excavation and hand sorting of twelve soil monoliths $(50 \mathrm{~cm} \times 50 \mathrm{~cm}$ wide, $30-50$ $\mathrm{cm}$ deep). During the vegetation period (April to September), data were collected monthly according to the soil-zoological method (Gilyarov 1965). Invertebrates visible without magnification were collected from successive strata (litter, $0-10 \mathrm{~cm}, 10-20 \mathrm{~cm}, 20-30 \mathrm{~cm}$ and $30-50 \mathrm{~cm}$ ) and sorted into broad taxonomic groups: Oligocheata, Isoptera, Isopoda, Arachnida, Chilopoda, Hemiptera, Coleoptera (adults and larvae), Diptera (larvae), Hymenoptera (mostly Formicidae) and others.

\section{RESULTS AND DISCUSSION}

Selecting indicator criteria for plant community assessment is essential for identifying key natural areas and corridors as basic structural components of an ecological network. Indicators of phytocenotic diversity reflect the structure of the analyzed cenofloras. For example, the core cenoflora of the rich forb-bunchgrass steppes, which are very close to the meadow steppes (with xeromesophytic and mesoxerophytic species of meadow steppes and natural steppes), have a maximum species diversity of nine to twelve species. The core cenoflora consists primarily of forb-bunchgrass, mesoxerophytic and euxerophytic steppe plants with a wide ecological niche. In comparison to the rich and polydominant communities of the meadow steppes, the diversity of species in the ranked list is lower. Diversity indices are much lower, and only the first six to nine species, which are considered common, make the main contribution to the total richness.

The core cenoflora of the bunchgrass steppes are euxerophytic and mainly bunch-forming grasses. Structurally Poa bulbosa plays a significant role. Phytocenotic diversity indicators for the arid semi-shrub-bunchgrass communities are very low. Feathergrass species are rare or absent, whereas sagebrush species are abundant (Artemisia lerchiana, A. austriaca, A. santonica). The abundance of species is lowest in the cenoflora of the petrophytic, psammophytic and halophytic vegetation.

The petrophytum is dominated by semi-shrubs (Artemisia hololeuca, A. salsoloides, Genista scythica, Hyssopus cretaceus, H. angustifolius, Hedysarum cretaceum, Thymus calcareus). Of these, only the first one to five species in the ranked list can be viewed as particularly abundant.

The core cenoflora of the psammophytic vegetation consists of psammophytic rhizome and bunch-forming grasses (Agropyron tanaiticum, Festuca beckeri), semi-shrubs (Artemisia arenaria) and shrubs (Salix rosmarinifolia, Chamaecytisus borysthenicus). The cenoflora richness is very low.

In the halophyte flora, Artemisia pauciflora and Poa bulbosa dominate the cenoflora and have the highest abundance. They have high densities, 
but only five species contribute significantly to the total plant abundance.

This approach has built a classification based on a detailed characterization of all vegetation units for the Rostov region. The syntaxonomy could then be used to evaluate the conservation importance of plant communities and to obtain a representative number of main and connecting areas as the fundamental basis for biodiversity conservation. The work performed to develop the econet enabled the data to be combined into a single geospatial information system.

Selection of criteria for conservation importance of plant communities is an important tool for highlighting the main components of an ecological network. The main principles of plant community assessment for conservation were formulated in papers on classic steppe research by E.M. Lavrenko (Lavrenko 1970, Lavrenko et al. 1991). Lavrenko's principles were further developed by other authors (Stoyko 1983) and general books such as the Green Book of Ukrainian SSR (Shelyak-Sosonko 1987), the Green Book of Siberia (Siberian Academy of Sciences 1996) and the Emerald Book of the Russian Federation (Institute of Geography of RAS 2013). At the international level, a system of species threat assessment and criteria to identify the most valuable habitats for conservation in Europe was elaborated through programs of international conservation organizations (WWF, IUCN), including the Global Strategy for Plant Conservation with its Important Plant Areas (IPA) and the Pan-European Biological and Landscape Diversity Strategy.

As we expected, the highest inclusion index (Table 2) was shown by rare mat grasses (Stipa pulcherrima, S. borysthenica, S. dasyphylla, S. pennata, S. tirsa, S. ucrainica, S. adoxa), which are the main components of steppe phytocenoses. There was also high inclusion of semi-shrub and semi-frutex species, which are common in petrophytic communitites (Hyssopus cretaceus, Scrophularia cretacea, Genista scythica, Artemisia hololeuca, A. salsoloides). This group also includes protected rare steppe taxa of bulb species or tulip ephemeroids (Bellevalia sarmatica, Hyacinthella pallasiana), which have a high inclusion index and are legally protected, though their cenotic role is less important.

The phytocenotic distribution of plant species listed in the Red Book of the Russian Federation and the Red Book of the Rostov Region is shown in Table 2.

Table 2: Phytocenotic distribution of plant species listed in the Red Book of the Russian Federation (Anon. 2008) and the Red Book of the Rostov Region (Anon. 2004) according to the studied plant communities

Tabela 2: Fitocenološka pripadnost rastlinskih vrst, naštetih v Rdečem seznamu Ruske Federacije (Anon. 2008) in Rdečem seznamu regije Rostov (Anon. 2004) v obravnavanih rastlinskih združbah.

Associations of Festuco-Brometea (Asociacije razreda Festuco-Brometea): 1 Trifolio alpestris-Stipetum tirsae, 2 Stipetum capillatae, 3 Festuco rupicolae-Stipetum dasyphyllae, 4 Bellevaliae sarmaticae-Stipetum pennatae, 5 Plantagini stepposae-Stipetum pulcherrimae, 6 Stipetum lessingianae, 7 Centaureo orientalis-Stipetum pulcherrimae, 8 Sileno wolgensis-Stipetum pulcherrimae, 9 Astragalo ponticae-Dianthetum leptopetali, 10 Ajugo orientalae-Festucetum pseudovinae, 11 Medicago romanicae-Stipetum ucrainicae, 12 Eryngio campestris-Stipetum ucrainicae, 13 Medicago romanicae-Festucetum valesiacae, 14 Astragalo asperi-Medicagetum romanicae, 15 Amorio retusae-Cerastietum syvaschici, 16 Agropyrini pectinati-Poetum bulbosae, 17 Artemisio lerchianae-Stipetum lessingianae, 18 Astragalo albicaulis-Stipetum capillatae, 19 Elytrigio trichophorae-Festucetum rupicolae, 20 Euphorbio seguieranae-Thymetum dimorphi, 21 Convolvulis lineati-Vincetoxietum maeotici, 22 Genisto scythicae-Stipetum adoxae.

\begin{tabular}{|c|c|c|c|c|c|c|c|c|c|c|c|c|c|c|c|c|c|c|c|c|c|c|}
\hline \multirow{2}{*}{$\begin{array}{l}\text { Classes } \\
\text { Association No. }\end{array}$} & \multicolumn{22}{|c|}{ Festuco-Brometea } \\
\hline & 1 & 2 & 3 & 4 & 5 & 6 & 7 & 8 & 9 & 10 & 11 & 12 & 13 & 14 & 15 & 16 & 17 & 18 & 19 & 20 & 21 & 22 \\
\hline Species number of site & 67 & 44 & 44 & 27 & 26 & 59 & 43 & 28 & 32 & 11 & 32 & 65 & 138 & 16 & 46 & 64 & 49 & 19 & 6 & 27 & 13 & 9 \\
\hline Stipa tirsa & 5 & 2 & 2 & 2 & 4 & . & . & 1 & . & . & 1 & . & . & 1 & . & . & . & . & . & . & . & . \\
\hline Stipa dasyphylla* & 3 & 3 & 4 & 5 & 2 & . & . & . & . & . & 2 & . & 1 & . & . & . & . & . & . & . & . & . \\
\hline Pulsatilla pratensis* & 1 & 1 & 2 & . & . & . & . & . & . & . & . & . & 1 & . & . & . & . & . & . & . & . & . \\
\hline Pulsatilla patens \| & 1 & 1 & 2 & . & . & . & . & . & . & . & . & . & . & . & . & . & . & . & . & . & . & . \\
\hline Iris pumila* & 1 & 1 & 2 & 1 & 1 & 2 & 2 & 1 & 3 & . & 1 & 2 & 1 & 1 & 1 & 1 & 1 & 1 & . & 4 & 3 & . \\
\hline Stipa pulcherrima* & 1 & 1 & . & 1 & 5 & . & 5 & 5 & 4 & . & 1 & . & 1 & . & . & . & . & 1 & . & 1 & . & 5 \\
\hline Bellevalia sarmatica* & 1 & 1 & . & 5 & 2 & 3 & 2 & 3 & 2 & 1 & 1 & 2 & 1 & 2 & 4 & 4 & . & . & . & 1 & . & . \\
\hline Paeonia tenuifolia* $*$ & 1 & 1 & . & 1 & . & . & 1 & . & . & . & . & . & . & . & . & . & . & 1 & . & . & . & . \\
\hline
\end{tabular}


Association No.

Campanula altaica

Centaurea ruthenica

Stipa zalesskii*\|

Platanthera bifolia

Fritillaria ruthenica*

Stipa ucrainica

Tulipa biebersteiniana

Koeleria talievii

Stipa borysthenica

Delphinium puniceum*

Campanula macrostachya

Eriosynaphe longifolia*

Hyacinthella pallasiana

Onosma tanaitica

Thymus calcareus

Asperula tephrocarpa

Elytrigia stipifolia*

Calophaca wolgarica*

Caragana scythica

Catabrosella humilis

Hedysarum grandiflorum*

Crocus reticulatus

Tulipa gesneriana*

Crambe tataria \|

Astragalus ponticus

Eremurus spectabilis*

Astragalus calycinus

Astragalus tanaiticus* $*$

Colchicum laetum*

Astragalus pubiflorus

Ventenata dubia

Astragalus physodes

Psathyrostachys juncea

Allium lineare

Cotoneaster alaunicus *

Cymbochasma borysthenica*

Anemone sylvestris

Cleome donetzica*

Scrophularia donetzica

Atraphaxis frutescens

Astragalus longipetalus

Allium regelianum *\|

Tulipa biflora

Iris scariosa*

Salvia austriaca

Linum hirsutum

Polygala cretacea

Artemisia salsoloides*

Diplotaxis cretacea

Polygala sibirica

Krascheninnikovia ceratoides

Delphinium schmalhausenii 
$\begin{array}{lllllllllllllllllllllll}\text { Association No. } & 1 & 2 & 3 & 4 & 5 & 6 & 7 & 8 & 9 & 10 & 11 & 12 & 13 & 14 & 15 & 16 & 17 & 18 & 19 & 20 & 21 & 22\end{array}$

Jurinea cyanoides $\|$

Silene hellmannii*

Euphorbia cretophila

Genista scythica

Total number of species

$\begin{array}{llllllllllllll}15 & 14 & 10 & 11 & 12 & 15 & 13 & 11 & 11 & 3 & 15 & 14 & 28 & 7\end{array}$

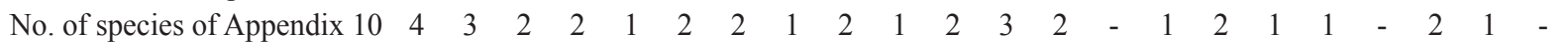

\section{Table 2 - cont.}

Associations of Helianthemo-Thymetea (Asociacije razreda Helianthemo-Thymetea): 23 Matthiolo fragransi-Atraphaxietum frutescens, 24 Hedysaro cretacei-Melicetum transsilvanicae, 25 Lepidio meyeri-Scrophularietum cretacei, 26 Erysimo cretaceiFestucetum cretacei, 27 Artemisio hololeucae-Polygaletum cretaceae, 28 Astragaletum albicaulis, 29 Genista scyticae-Artemisietum salsoloidis, 30 Sileno borysthenicae-Hyssopetum angustifolii.

Associations of Festucetea vaginatae (Asociacije razreda Festucetea vaginatae): 31 Secalo-Stipetum borysthenicae, 32 Hieracio echioidis-Stipetum borysthenicae, 33 Scirpoido-Genistaetum sibiricae, 34 Artemisio arenariae-Potentilletum astracanicae, 35 Artemisio arenariae-Festucetum beckeri, 36 Centaureo gerberi-Agropyretum tanaitici.

Association of Festuco-Puccinellietea (F-P) (Asociacije razreda Festuco-Puccinellietea) 37 Poo bulbosae-Artemisietum pauciflorae.

\begin{tabular}{|c|c|c|c|c|c|c|c|c|c|c|c|c|c|c|c|}
\hline Classes & & & Helia & them & -Thy & neted & & & & Fest & ceter & vagi & atae & & $F-P$ \\
\hline Association No. & 23 & 24 & 25 & 26 & 27 & 28 & 29 & 30 & 31 & 32 & 33 & 34 & 35 & 36 & 37 \\
\hline Species number of site & 11 & 4 & 5 & 12 & 8 & 7 & 8 & 3 & 16 & 36 & 10 & 5 & 38 & 33 & 22 \\
\hline Hyssopus cretaceus* & 5 & 5 & 5 & 3 & 5 & 4 & . & . & . & . & . & . & . & . & . \\
\hline Artemisia salsoloides* & 3 & 5 & 5 & . & 4 & 5 & 5 & . & . & . & . & . & . & . & 1 \\
\hline Festuca cretacea & 1 & . & 2 & 5 & . & 3 & . & . & . & . & . & . & . & . & . \\
\hline Asperula tephrocarpa & 5 & . & . & 1 & 4 & 3 & 4 & . & . & . & . & . & . & . & . \\
\hline Thymus calcareus & 2 & . & . & 1 & 5 & 3 & 5 & 5 & . & . & . & . & . & . & . \\
\hline Onosma tanaitica & 1 & . & . & 1 & 2 & 2 & 5 & . & & . & . & . & . & . & . \\
\hline Matthiola fragrans* & 5 & . & . & . & 3 & . & . & . & . & . & . & . & . & . & . \\
\hline Atraphaxis frutescens & 3 & . & . & . & . & . & . & . & . & . & . & . & . & . & . \\
\hline Silene cretacea* $*^{*}$ & 2 & . & . & . & . & . & . & . & . & . & . & . & . & . & . \\
\hline Serratula tanaitica* $\|$ & 1 & . & . & . & . & . & . & . & . & . & . & . & . & . & . \\
\hline Krascheninnikovia ceratoides & 1 & . & . & . & . & . & . & . & . & . & . & . & . & . & . \\
\hline Hedysarum cretaceum* & . & 5 & . & . & . & . & . & . & . & . & . & . & . & . & . \\
\hline Scrophularia cretacea & . & 3 & 5 & 2 & 2 & 3 & . & . & . & . & . & . & . & . & . \\
\hline Lepidium meyeri ${ }^{*}$ & . & . & 5 & . & . & . & . & . & . & . & . & . & . & . & . \\
\hline Polygala cretacea & . & . & . & 2 & 1 & . & 2 & . & . & . & . & . & . & . & . \\
\hline Erysimum cretaceum & . & . & . & 2 & . & . & . & . & . & . & . & . & . & . & . \\
\hline Linum hirsutum & . & . & . & 1 & . & . & 2 & . & . & . & . & . & . & . & . \\
\hline Erucastrum cretaceum* & . & . & . & 1 & . & . & 1 & . & . & . & . & . & . & . & . \\
\hline Anemone sylvestris & . & . & . & 1 & . & . & . & . & . & . & . & . & . & . & . \\
\hline Angelica archangelica & . & . & . & 1 & . & . & . & . & . & . & . & . & . & $\cdot$ & . \\
\hline Chaenorhinum klokovii & . & . & . & 1 & . & . & . & . & . & . & . & . & . & $\cdot$ & . \\
\hline Corylus avellana & . & . & . & 1 & . & . & . & . & . & . & $\cdot$ & $\cdot$ & . & $\cdot$ & $\cdot$ \\
\hline Artemisia hololeuca* & . & . & . & . & 5 & . & . & . & . & $\cdot$ & . & . & · & · & · \\
\hline Linum ucrainicum & . & . & . & . & 5 & . & . & . & . & . & . & . & . & . & . \\
\hline Jurinea cretacea* & . & . & . & . & . & 1 & . & . & . & . & . & . & . & . & . \\
\hline Stipa pulcherrima* & . & . & . & . & . & 1 & 3 & . & . & 1 & . & . & . & . & . \\
\hline Euphorbia cretophila & . & . & . & . & . & . & 5 & . & . & . & . & . & . & . & . \\
\hline Genista scythica & . & . & . & . & . & . & 5 & . & . & . & . & . & . & . & . \\
\hline Centaurea ruthenica & . & . & . & . & . & . & 4 & . & . & . & . & . & . & · & · \\
\hline Hedysarum grandiflorum* & . & . & . & . & . & . & 4 & . & . & . & . & . & . & . & . \\
\hline Hyacinthella pallasiana & . & . & . & . & . & . & 3 & . & . & . & . & . & . & . & . \\
\hline Diplotaxis cretacea & . & . & . & . & . & . & 2 & . & . & . & . & . & . & . & . \\
\hline
\end{tabular}




\begin{tabular}{|c|c|c|c|c|c|c|c|c|c|c|c|c|c|c|c|}
\hline \multirow{2}{*}{$\begin{array}{l}\text { Classes } \\
\text { Association No. }\end{array}$} & \multicolumn{8}{|c|}{ Helianthemo-Thymetea } & \multicolumn{6}{|c|}{ Festucetea vaginatae } & \multirow{2}{*}{$\begin{array}{c}F-P \\
37\end{array}$} \\
\hline & 23 & 24 & 25 & 26 & 27 & 28 & 29 & 30 & 31 & 32 & 33 & 34 & 35 & 36 & \\
\hline Elytrigia stipifolia* & . & . & . & . & . & . & . & 4 & . & & . & . & . & . & . \\
\hline Stipa borysthenica & . & . & . & . & . & . & . & . & 5 & 5 & 3 & 3 & 1 & 1 & . \\
\hline $\begin{array}{l}\text { Centaurea gerberi }(=C \text {. } \\
\text { dubjanskyi })^{*} \|\end{array}$ & . & . & . & . & . & . & . & . & 1 & 1 & . & . & . & 5 & . \\
\hline Astragalus tanaiticus $* \|$ & . & . & . & . & . & . & . & . & 1 & 1 & . & . & . & . & . \\
\hline Jurinea cyanoides \| & . & . & . & . & . & . & . & . & 1 & 1 & . & . & . & . & . \\
\hline Pulsatilla pratensis* & . & . & . & . & . & . & . & . & 1 & 1 & . & . & 1 & 1 & . \\
\hline Pulsatilla patens \| & . & . & . & . & . & . & . & . & . & 1 & . & . & . & . & . \\
\hline Allium savranicum & . & . & . & & . & . & . & . & . & 1 & . & . & . & . & . \\
\hline Koeleria talievii & . & . & . & . & . & . & . & . & . & 1 & . & . & . & . & . \\
\hline Astragalus longipetalus & . & . & . & . & . & . & . & . & . & 1 & . & . & . & . & . \\
\hline Iris pumila* & . & . & . & . & . & . & . & . & . & 1 & . & 4 & . & . & 1 \\
\hline Stipa pennata* & . & . & . & . & . & . & . & . & . & 1 & . & 2 & . & . & . \\
\hline Allium regelianum $* \|$ & . & . & . & . & . & . & . & . & . & . & 1 & . & . & . & . \\
\hline Astragalus calycinus & . & . & . & . & . & . & . & . & . & . & . & 1 & . & . & . \\
\hline Stipa ucrainica & . & . & . & . & . & . & . & . & . & . & . & 1 & . & . & 1 \\
\hline Dianthus squarrosus & . & . & . & . & . & & . & . & . & . & . & . & 2 & 1 & \\
\hline Juniperus sabina & . & . & . & . & . & . & . & . & . & . & . & . & 1 & . & . \\
\hline Bellevalia sarmatica* & . & . & . & . & . & . & . & . & . & . & . & . & . & . & 1 \\
\hline Tulipa biebersteiniana & . & . & . & . & . & . & . & . & . & . & . & . & . & . & 2 \\
\hline Tulipa gesneriana* & . & . & . & . & . & . & . & . & . & . & . & . & . & . & 1 \\
\hline Ventenata dubia & . & . & . & . & . & . & . & . & . & . & . & . & . & . & 2 \\
\hline Tulipa biflora & . & . & . & . & . & . & . & . & . & . & . & . & . & . & 1 \\
\hline Total number of species & 11 & 4 & 5 & 14 & 10 & 9 & 14 & 2 & 5 & 12 & 2 & 5 & 4 & 4 & 8 \\
\hline Number of species of Appendix 10 & 2 & - & - & - & - & - & - & - & 1 & 2 & 1 & - & - & - & - \\
\hline
\end{tabular}

* Species listed in the Red Book of the Russian Federation; || - species listed in Appendix 10 "Species requiring specific habitat conservation measures"; species inclusion index: 1 singly occurrence, very rare (the species was mentioned in a one or few descriptions); 2 rare (low number of mentions in descriptions); 3 sporadical (medium number of mentions in descriptions); 4 common (medium and high number of mentions in descriptions); 5 most common (highest number of mentions in descriptions).

We used criterion A to analyze rare plant phytocenotic distributions (Table 2 and Table 3 ), which included 85 protected species from the studied communities. 35 of these species are listed in the Red Book of the Russian Federation (Anon. 2008), and 50 of these species are listed in the Red Book of the Rostov Region (Anon. 2004). Unfortunately, the flora of the associations described above contains many local endemics of the Don basin and the Azov area (Genista scythica, Hyacinthella pallasiana, Onosma tanaitica and others), which are only regionally protected. Criterion A (v) is therefore important to assess conservation communities and Areas of Special Conservation Interest (ASCIs).

The eleven species Allium regelianum, Astragalus tanaiticus, Crambe tataria, Centaurea dubjanskyi, Jurinea cyanoides, Echium russicum, Paeonia tenuifolia, Pulsatilla patens, Serratula tanaitica, Silene cretacea, Stipa zalesskii are listed in Appendix 10 of the Bern Convention (Standing Committee of the Bern Convention 2011). Of these eleven, only seven species are listed in the Red Books of the Russian Federation and Rostov Region; three species (Crambe tataria, Echium russicum, Pulsatilla patens) are protected species only inside the Rostov Region; one species (furinea cyanoides) is not legally protected in Russia.

Most abundant among the rare species are communities of five associations: Medicago romanicae-Festucetum valesiacae (28 species), Euphorbio seguieranae-Thymetum dimorphi (19 species), Medicago romanicae-Stipetum ucrainicae (16 species), Stipetum lessingianae (15 species) and Trifolio alpestris-Stipetum tirsae (15 species). These communities have the highest index value (A (v) 1). One association of Trifolio alpestris-Stipetum tirsae includes the largest number of species (four species) of Appendix 10 of the Bern Convention (Standing Committee of the Bern Convention 2011). 14 associations have no Appendix 10 species. The EUNIS code for European habitat classification was applied to define typological and eco-floristic classification 
Table 3: Conservation priority assessment for steppe plant communities in the Don basin.

Tabela 3: Ocena varstvene prioritete stepskih rastlinskih združb porečja reke Don.

\begin{tabular}{|c|c|c|c|c|c|}
\hline Associations / Criteria & A & EUNIS & $\mathrm{R}$ & $\mathrm{N}$ & $\mathrm{F}$ \\
\hline \multicolumn{6}{|l|}{ Class FESTUCO-BROMETEA } \\
\hline Trifolio alpestris-Stipetum tirsae & $\mathrm{A}(\mathrm{v}) 1$ & E1.2 & R 2 & N 1 & F 2 \\
\hline Bellevaliae sarmaticae-Stipetum pennatae & $A(v) 2$ & E1.2 & R 7 & N 0 & F 1 \\
\hline Centaureo orientalis-Stipetum pulcherrimae & $\mathrm{A}(\mathrm{v}) 2$ & E1.2 & R 3 & N 1 & F 3 \\
\hline Plantagini stepposae-Stipetum pulcherrimae & $A(v) 3$ & E1.2 & R 4 & N 2 & F 2 \\
\hline Stipetum capillatae & $A(v) 2$ & E1.2 & $\mathrm{R} 2$ & $\mathrm{~N} 2$ & F 3 \\
\hline Festuco rupicolae-Stipetum dasyphyllae & $\mathrm{A}(\mathrm{v}) 2$ & E1.2 & R 2 & $\mathrm{~N} 2$ & F 3 \\
\hline Sileno wolgensis-Stipetum pulcherrimae & $A(v) 2$ & E1.2 & R 2 & N 1 & F 3 \\
\hline Astragalo ponticae-Dianthetum leptopetali & $A(v) 2$ & E1.2 & R 7 & N 3 & F 1 \\
\hline Ajugo orientalae-Festucetum pseudovinae & $\mathrm{A}(\mathrm{v}) 4$ & E1.2 & R 6 & N 2 & F 3 \\
\hline Stipetum lessingianae & $\mathrm{A}(\mathrm{v}) 1$ & E1.2 & R 2 & N 1 & F 2 \\
\hline Medicago romanicae-Stipetum ucrainicae & $\mathrm{A}(\mathrm{v}) 1$ & E1.2 & $\mathrm{R} 2$ & N 1 & F 2 \\
\hline Astragalo albicaulis-Stipetum capillatae & $A(v) 2$ & E1.2 & R 7 & N 1 & F 2 \\
\hline Elytrigio trichophorae-Festucetum rupicolae & $A(v) 3$ & E1.2 & R 7 & N 1 & F 1 \\
\hline Euphorbio seguieranae-Thymetum dimorphi & $\mathrm{A}(\mathrm{v}) 1$ & E1.3 & R 7 & N 1 & F 1 \\
\hline Convolvulis lineati-Vincetoxietum maeotici & $A(v) 3$ & E1.2 & $\mathrm{R} 2$ & N 1 & F 3 \\
\hline Genisto scythicae-Stipetum adoxae & $A(v) 2$ & E1.3 & R 7 & $\mathrm{~N} 4$ & F 1 \\
\hline Medicago romanicae-Festucetum valesiacae & $\mathrm{A}(\mathrm{v}) 1$ & E1.3 & $\mathrm{R} 2$ & N 1 & F 2 \\
\hline Eryngio campestris-Stipetum ucrainicae & $\mathrm{A}(\mathrm{v}) 2$ & E1.2 & R 2 & N 3 & F 3 \\
\hline Astragalo asperi-Medicagoetum romanicae & $A(v) 3$ & E1.3 & R 3 & N 0 & F 2 \\
\hline Amorio retusae-Cerastietum syvaschici & $A(v) 3$ & E6.2 & R 5 & N 1 & F 2 \\
\hline Agropyrini pectinati-Poetum bulbosae & $A(v) 3$ & E6.2, X29 & R 5 & N 1 & F 2 \\
\hline Artemisio lerchianae-Poetum bulbosae & $A(v) 2$ & E6.2 & R 5 & $\mathrm{~N} 1$ & F 1 \\
\hline \multicolumn{6}{|l|}{ Class FESTUCETEA VAGINATAE } \\
\hline Secalo-Stipetum borysthenicae & $A(v) 3$ & E1.2 & R 1 & N 1 & F 4 \\
\hline Hieracio echioidis-Stipetum borysthenicae & $A(v) 2$ & $\mathrm{E} 1.2, \mathrm{X} 35$ & R 1 & N 1 & F 3 \\
\hline Scirpoido-Genistaetum sibiricae & $\mathrm{A}(\mathrm{v}) 4$ & E1.2 & R 5 & N 3 & F 3 \\
\hline Artemisio arenariae-Potentilletum astracanicae & $A(v) 3$ & $\mathrm{X} 35$ & R 5 & N 1 & F 2 \\
\hline Artemisio arenariae-Festucetum beckeri & $A(v) 3$ & $\mathrm{X} 35$ & R 0 & N 1 & F 3 \\
\hline Centaureo gerberi-Agropyretum tanaitici & $A(v) 3$ & $\mathrm{X} 35$ & R 5 & N 3 & F 1 \\
\hline \multicolumn{6}{|l|}{ Class HELIANTHEMO-THYMETEA } \\
\hline Matthiolo fragransi-Atraphaxietum frutescens & $A(v) 2$ & E1.3 & R 7 & N 1 & F 2 \\
\hline Hedysaro cretacei-Melicetum transsilvanicae & $A(v) 3$ & E1.3 & R 7 & No & F 1 \\
\hline Lepidio meyeri-Scrophularietum cretacei & $A(v) 3$ & E1.3 & R 7 & N 0 & F 1 \\
\hline Erysimo cretacei-Festucetum cretacei & $A(v) 2$ & E1.3 & R 7 & N 3 & F 2 \\
\hline Artemisio hololeucae-Polygaletum cretaceae & $A(v) 2$ & E1.3 & R 7 & N 0 & F 1 \\
\hline Genisto scythicae-Artemisietum salsoloidis & $\mathrm{A}(\mathrm{v}) 2$ & E1.3 & R 7 & $\mathrm{~N} 4$ & F 1 \\
\hline Sileno borysthenicae-Hyssopetum angustifolii & $\mathrm{A}(\mathrm{v}) 4$ & E1.3 & R 7 & N 0 & F 1 \\
\hline \multicolumn{6}{|l|}{ Class FESTUCO-PUCCINELLIETEA } \\
\hline Poo bulbosae-Artemisietum pauciflorae & $\mathrm{A}(\mathrm{v}) 3$ & E6.2, X29 & R 0 & N 1 & F 4 \\
\hline
\end{tabular}

Notes

Criteria: A (v) 1 - species occurrence in geobotanic descriptions below $20 \%$; A (v) 2 - up to $40 \%$; A (v) 3 - up to $60 \%$; A (v) 4 - up to $80 \%$; C (I) - prior conservation habitats; C (II) - threatened habitats.

units identified in the study area. In total, we identified five habitats as EUNIS association communities: E1.2 Perennial calcareous grassland and ba- sic steppes, E1.3 Mediterranean xeric grasslands, E6.2 Continental inland salt steppes, X29 Salt lake islands and X35 Inland sand dunes (Table 3). 
A critical issue is that EUNIS does not represent the entire array of steppe habitats of the Don basin. E1.3 (Mediterranean xeric grasslands) of EUNIS are described as "Meso- and thermo-Mediterranean xerophile, mostly open, short-grass perennial grasslands rich in therophytes; therophyte communities of oligotrophic soils on base-rich, often calcareous substrates". In contrast to this description, petrophyte communities in the steppe part of the Don basin are often represented by semi-frutex and semi-shrub cenoses known as "steppe tomillars" (Didukh 1989, Didukh \& Korotchenko 1996), but not by grasslands. Whereas therophytes are very rare in the steppe tomillars, semi-shrub and semi-frutex species are important the main components of steppe phytocenoses, as well as perennial grass tulips, which often are ephemeroids and hemiephemeroids. Hence, adapting the EUNIS classification to the Don basin steppes may require some new habitats to be included in EUNIS. These new EUNIS habitats should be plain communities of petrophytes that grow on rock outcrops of chalk, limestone, clay and sandy shale. Syntaxonomically these communities relate to associations of the class Helianthemo-Thymetea: Matthiolo fragrandis-Atraphaxietum frutescens, Hedysaro cretacei-Melicetum transsilvanicae, Lepidio meyeriScrophularietum cretacei, Erysimo cretacei-Festucetum cretacei, Centaureo carbonatae-Onosmetum tanaiticae, Artemisio hololeucae-Polygaletum cretaceae, Genisto scythicae-Artemisietum salsoloidis and Sileno borysthenicae-Hyssopetum angustifolii.

Consequently, we have built our plant community assessment on the basis of bio-ecological parameters of biodiversity conservation, which include community range reduction tendencies and community rarity (Martynenko \& Mirkin 2006). These location and legal factors not only substantially affect the indices, but are also necessary to support sustainability and biodiversity in our region. Thus, it seemed appropriate to include these factors in our criteria. Table 3 illustrate that the floristic-phytocenological index $(\mathrm{F})$ of a higher association increases with the number of endemic, relict and other rare species or border range species. The top F1 associations featured species combinations of various classes, habitat border locations, species abundance and structural complexity.

The largest group is formed by petrophyte communities, which are often successional. In these communities the strongest ecotone effects are found. Associations are: Astro amelli-Elytrige- tum trichophorae, Cephalario uralensidis-Thymetum dimorphi, Genisto scythicae-Stipetum adoxae within the class Festuco-Brometea, and other associations that include petrophyte communities: Hedysaro cretacei-Melicetum transsilvanicae, Lepidio meyeriScrophularietum cretacei, Artemisio hololeucae-Polygaletum cretaceae, Genisto scythicae-Artemisietum salsoloidis and Sileno borysthenicae-Hyssopetum angustifolii in the class Helianthemo-Thymetea.

High F1 index values were also assigned to Festuco-Brometea associations: Bellevaliae sarmaticae-Stipetum pennatae and Astragalo ponticae-Brometum squarrosi, which enclose pelitophyte and hemi-psammophyte variations of multi-grass and bunch-gramineous steppes (Figure 1) - Pontic steppes; and hemi-halophyte communities of the desertified semi-shrub and bunch-gramineous association Artemisio lerchianae-Poetum bulbosae (Figure 2) - Trans-Volga-Kazakh steppes.

In the Festucetea vaginatae class, only the association Centaureo gerberi-Agropyretum tanaitici has attained the highest index value F1.

All other associations have lower values of the F index (Table 3).

As mentioned above, we consider the $\mathrm{F}$ index to be the most important aggregate indicator for assessing conservation priority of plant communities. The $\mathrm{F}$ index is also important because it correlates with other indexes. For example, the highest floristic-phytocenological index value (F1) corresponds in most cases with the highest rarity index value (R7).

Summarizing all the indexes for our Don basin study area, we conclude that the highest conservation priority is attained by steppe hemi-psammophyte Bellevaliae sarmaticae-Stipetum pennatae communities (EUNIS - E1.2) and petrophyte associations of Hedysaro cretacei-Melicetum transsilvanicae, Lepidio meyeri-Scrophularietum cretacei, Artemisio hololeucae-Polygaletum cretaceae and Sileno borysthenicae-Hyssopetum angustifolii (EUNIS E1.3) These communities have a restricted range and are classified as threatened with extinction, but they remain outside protected areas (Table 3 ).

Table 3 illustrates the relative abundance of soil invertebrates in different regions. The abundance was twice as high for temperate-arid rich forb-feather grass steppes on ordinary chernozem than for arid-forb-feather grass steppes on souther chernozem and three times higher than for the temperate-dry bunch grass steppes on dark chestnut soils of the Kostanay region. This was broadly in line with survey indicators of vegetation. 


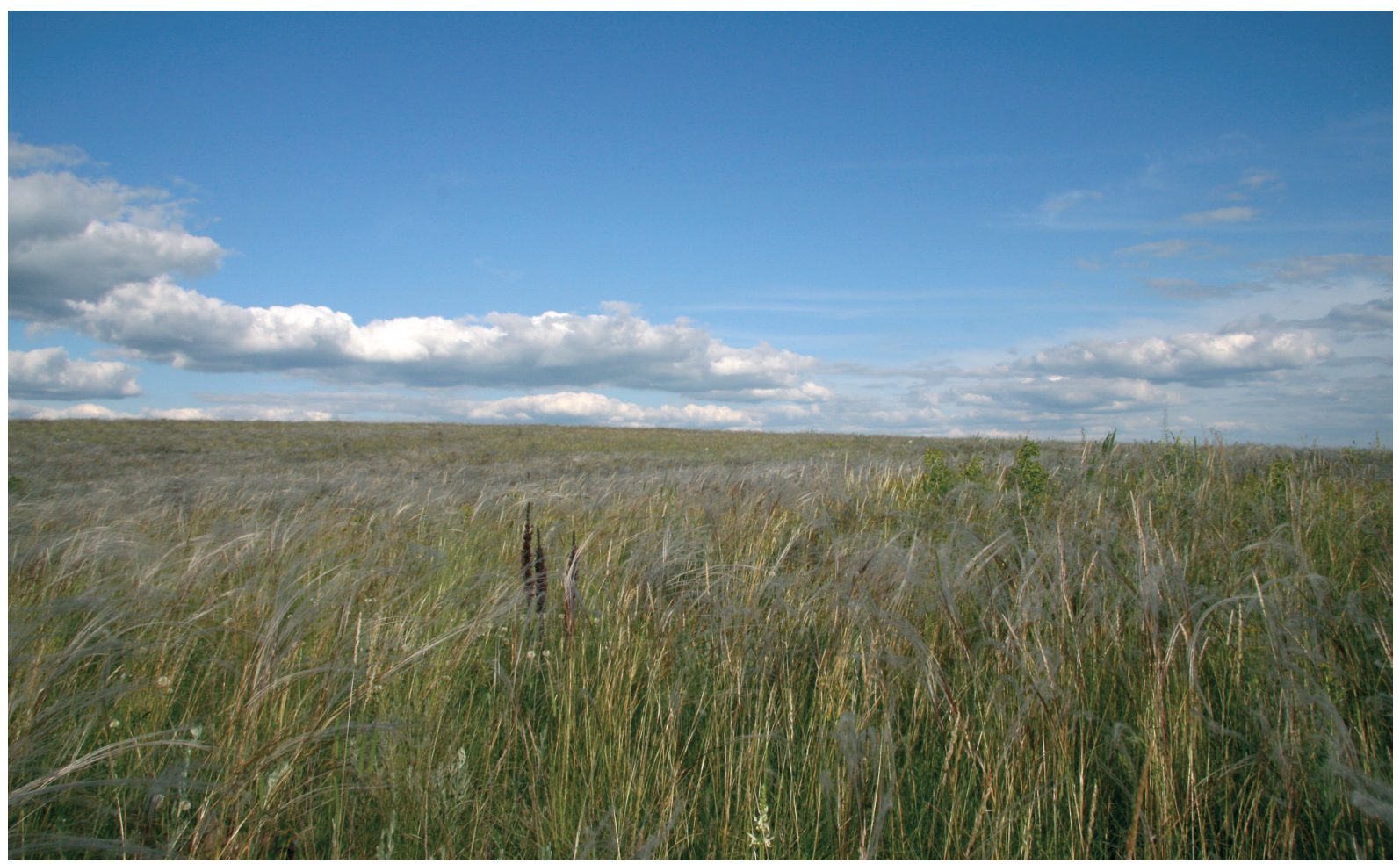

Figure 1: Pontic steppes (of the Black Sea area) of the Don basin. Slika 1: Pontske stepe (ob Črnem morju) porečja reke Don.

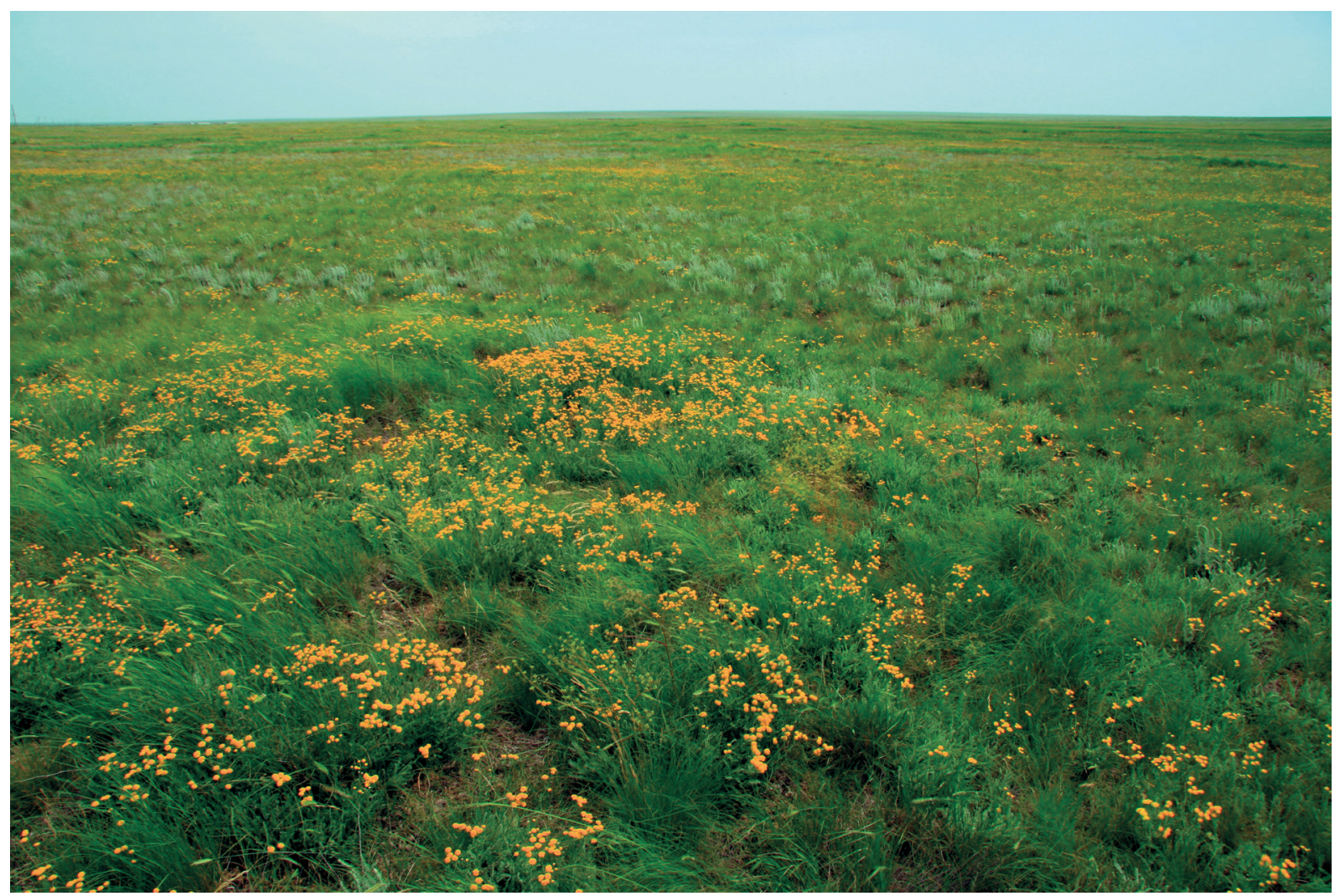

Figure 2: Trans-Volga-Kazakh steppes of the Don basin.

Slika 2: Trans-Volga-Kazahstanske stepe porečja reke Don. 
The vegetation cover of the Kostanay region (Kazakhstan), where the Trans-Volga-Kazakhstan steppes are common, is rich and diverse (Bragina 2007, Rachkovskaya \& Bragina 2012). The region provides a full range of basic zonal steppe categories found in Kazakhstan as well as small areas of southern forest-steppe and northern desert. The Kazakh steppe is divided into five subzones:

1. Temperate-droughty rich forb-feather grass steppes on normal chernozem. The indigenous steppe type of this area is a rich forb (Peucedanum morisonii)-red feather grass (Stipa zalesskii) steppe. Currently, most of the rich forb-grass steppe is plowed.

2. Droughty forb-feather grass steppe on southern chernozem. In these steppes Stipa zalesskii and Festuca valesiaca are dominant species, and Koeleria cristata is a co-dominant; forbs are less abundant.

3. Temperate-dry bunch grass steppes on dark chestnut soils include xerophytic bunch grasses (Stipa lessingiana, S. capillata, Festuca valesi$a c a$ ), loose bunch grasses (Agropyron pectinatum) and rhizome grasses (Leymus ramosus) with little occurrence of forbs.
4. Dry xerophytic forb-bunch grass steppes on chestnut soils. The main zonal type is a xerophytic forb-fescue-feather grass steppe (Stipa lessingiana, Festuca valesiaca, Galatella ivaricata, G. tatarica, Phlomoides agraria, Tanacetum achilleifolium), which can be regarded as a southern version of the dry steppe.

5. Desert sagebrush-bunch grass steppes on light chestnut soils include the sagebrush-feather grass steppes with Stipa lessingiana and species of the genus Artemisia in the northern part and Stipa sareptana and Artemisia spp. in the southern part. The vegetation of the desert steppe is more complex; it is the southernmost type of steppe in the region.

Associated with the changes of vegetation and soil animal communities, we also see changes in vegetation productivity and type of soil (Bragina 2004). Specifically, high soil and vegetation productivity usually indicates high biological activity and abundance and diversity of the soil fauna, which was shown for the soil invertebrate communities (macro fauna) of Kazakh steppes and abundance of soil invertebrates in the main subzonal steppes of the Kostanay region (Table 4).

Table 4: The composition and abundance of soil invertebrate communities (\%) of the sub-zones of the Kazakh steppes (macrofauna) in the Kostanay region.

Tabela 4: Vrstna sestava in abundanca združb talnih nevretenčarjev (\%) v območjih Kazahstanske stepe (makrofavna) v regiji Kostanay.

\begin{tabular}{lccc}
\hline Composition & $\begin{array}{c}\text { Rich forb-feather grass steppe } \\
\text { on normal chernozem }\end{array}$ & $\begin{array}{c}\text { Forb-feather grass steppes } \\
\text { on southern chernozem }\end{array}$ & $\begin{array}{c}\text { Bunch grass steppes } \\
\text { on dark chestnut soils }\end{array}$ \\
\hline Lumbricidae & 2.2 & - & - \\
Opiliones & 2.2 & 0.2 & + \\
Aranei & 7.1 & 6.6 & 6.6 \\
Geophilidae & 15.2 & 0.4 & + \\
Dermaptera & 9.3 & - & - \\
Hemiptera & 4.0 & 1.2 & 4.3 \\
Carabidae & 9.4 & 3.6 & 3.3 \\
Scarabaeidae & 5.4 & 5.4 & 46.4 \\
Elateridae & 19.2 & 33.7 & 4.6 \\
Alleculidae & - & - & 1.3 \\
Tenebrionidae & - & 1.2 & 5.3 \\
Curculionidae & 9.7 & 20.9 & 14.2 \\
Other beetles & 1.3 & 2.4 & 1.0 \\
Lepidoptera & 2.2 & 1.8 & 2.1 \\
Hymenoptera & 1.6 & 4.2 & 1.0 \\
Diptera & 6.3 & 11.9 & 8.3 \\
Others & 4.9 & 6.5 & 1.6 \\
Total: & 100.0 & 100.0 & 100.0 \\
Abundance $\mathrm{m}^{2}$ & 89.6 & 44.2 & 30.3 \\
Abundance per sample & & & $7.6 \pm 0.9$ \\
(0.25 $\mathrm{m}^{2}$ Mean \pm s.e. & $22.4 \pm 1.3$ & $11.1 \pm 1.7$ & \\
\hline
\end{tabular}


Soil-dwelling invertebrates regulate microbial activity, soil aggregation and dynamics of decomposition of soil organic matter. They are therefore, together with soil microorganisms, important in the construction of soil profile, vegetation cover and maintenance of soil fertility.

Thus, the combination of quantitative assessment criteria and phytocentral floristic diversity, selection of habitat types according to the EUNIS classification and expert analysis provides a new approach to the determination of the overall protection priority of plant community steppes of the Don basin and has great potential in the field of biodiversity conservation.

Using these criteria our analysis demonstrated 37 associations from the four classes of ecofloristic classification of steppe vegetation in the Don basin: Festuco-Brometea, Festucetea vaginatae, Helianthemo-Thymetea and Festuco-Puccinellietea (Table 4). As a result, we obtain a new idea of the importance of the plant communities of the Black Sea and Kazakhstan steppes.

Sites with a high floristic-phytocenological index value (F1) were identified as key areas for the further development of a national, regional and local scale econet. According to our analysis, the highest conservation priorities are given to the steppe hemi-psammophyte Bellevaliae sarmaticaeStipetum pennatae communities and petrophyte associations of Hedysaro cretacei-Melicetum transsilvanicae, Lepidio meyeri-Scrophularietum cretacei, Artemisio hololeucae-Polygaletum cretaceae and Sileno borysthenicae-Hyssopetum angustifolii. These communities have a restricted range and are classified as endangered, but they remain outside protected areas.

Associated with the changes of vegetation and soil animal communities, we also see changes in vegetation productivity and soil type in places including the Kostanai region in Kazakhstan. High soil and vegetation productivity usually indicates high biological activity and diversity of the soil fauna, the combination of which is essential for constructing the Pan-European Ecological Network.

\section{ACKNOWLEDGMENTS}

The authors gratefully acknowledge all the supporters who assisted in field observations and laboratory analyses as well as those who contributed to this article in other ways, including providing comments and discussion. Last but not least the authors wish to thank Rosario Gavilán for editorial handling, Aiko Huckauf for linguistic editing and the European Dry Grassland Group (EDGG) that made this possible through a grant from IAVS.

\section{REFERENCES}

Anderson, S. 2003: Identification of the important plant areas: Guidelines for site selection in $\mathrm{Eu}-$ rope and the basis for the development of the rules for the world [in Russian]. Publishing House of the World Conservation Union (IUCN) to Russia and the CIS, Moscow, 39 pp.

Andreev, A. V. 2002: Biodiversity assessment, monitoring and ecological network [in Russian]. Biotica, Chisinau, 168 pp.

Anon. 2004: Red Book of the Rostov region: rare and end angered plant species [in Russian]. Rostov-on-Don, 333 pp.

Anon. 2006: The strategy of conservation of the steppes of the Russia: the position of non-governmental organizations [in Russian]. Publishing House of the Center for Biodiversity Conservation, Moscow, 36 pp.

Anon. 2008: Red Book of the Russian Federation (plants and fungi) [in Russian]. KMK Scientific Press, Moscow, 855 pp.

Berg, C., Abdank, A., Isermann, M., Jansen, F., Timmermann, T. \& Dengler, J. (in press): Red Lists and conservation prioritization of plant communities - a methodological framework. Applied Vegetation Science. DOI: 10.1111/ avsc. 12093.

Bragina, T. M. 2004: Comparative analysis of the population of soil invertebrates of steppes and fallow lands in the sub zone of moderately dry steppe of Kazakhstan [in Russian]. Proceedings of the National Academy of Sciences of Kazakhstan. Biological and Medical Series 4: 25-30.

Bragina, T. M. 2007: Protected areas of Kazakhstan and the prospects for establishment of ecological network (with a legislative framework for protected areas) [in Russian]. Kostanai Printing House, Kostanay, 164 pp.

Braun-Blanquet, J. 1964: Pflanzensoziologie. Grundzüge der Vegetationskunde. 3rd. ed. Springer, Wien, $865 \mathrm{pp}$.

De Deyn, G. B., Quirk, H. \& Bardgett, R. D. 2011: Plant species richness, identity and productiv- 
ity differentially influence key groups of microbes in grassland soils of contrasting fertility. Biological Letters 7: 75-78.

Demina, O. N. 2007: Formation of the system of natural monuments in the Rostov region [in Russian]. IUCN, Rostov-on-Don, 79 pp.

Demina, O. N. 2011: Patterns of distribution and development of the vegetation of the steppes of the Don Basin (within the Rostov region) [in Russian]. Abstract of the doctoral dissertation. Moscow, $50 \mathrm{pp}$.

Demina, O. N. 2012: East Black-Sea forb-bunchgrass steppes of Don basin (within the Rostov region) [in Russian]. Vegetation Russia 2: 27-47.

Didukh, Y. P. 1989: Floristic classification of "gypsum flora" groups [in Ukrainian]. Ukrainian Botanic Journal 46(6): 16-21.

Didukh, Y. P. \& Korotchennko, I. A. 1996: Steppe vegetation of the southern Ukrainian Left Bank forest-steppe region. I. Classes Festucetea vaginatae and Helianthemo-Thymetea [in Ukrainian]. Ukranian Phytocen Almanac, Series A, 2: 56-63.

Gilyarov, M. S. 1965: Zoological diagnostic method of soil [in Russian]. Nauka, Moscow, 278 p.

Institute of Geography of RAS (ed.) 2013: Emerald Book of the Russian Federation. Areas of special conservation interest in European Russia. Proposals on ASCI identification. Part 1, $M$ [in Russian]. Institute of Geography of RAS, 308 pp.

Izco, J. 1998: Types of rarity of plant communities. Journal of Vegetation Science 9: 641-646.

Lavelle, P. \& Pashanasi, B. 1989: Soil macrofauna and land management in Peruvian Amazonia (Yurimaguas, Loreto). Pedobiologia 33: 283-291.

Lavrenko, E. M. 1970: The provincial division of the Black Sea-Kazakhstan subregion of steppe region of Eurasia [in Russian]. Botanical Journal 55: 609-625.

Lavrenko, E. M., Karamysheva, Z. V. \& Nikulina, R. I. 1991: Steppes of Eurasia [in Russian]. Nauka, Leningrad, 146 pp.

Lysenko, T., Mucina, L. \& Iakushenko, D. 2011: Nomenclatural notes on saline vegetation of Ukraine, southern Russia and Kazakhstan. Lazaroa 32: 187-189.

Martynenko, V. B. \& Mirkin, B. M. 2006: The role of vegetation classification in designing a system of protected areas. Questions of general botany: traditions and prospects [in Russian]. In: Proceedings of the international sci- entific conference dedicated to the 200th anniversary of Kazan botanical school. Part 2, Kazan, pp. 301-303.

Rabinowitz, D., Cairms, S. \& Dillon, T. 1986: Seven forms of rarity and their frequencies in the flora of British isles. In: Soule, M. E. (ed.): Conservation biology: The science of scarcity and scarcity and diversity. Sinaver, Sunderland, pp. 182-204.

Rachkovskaya, E. I. \& Bragina, T. M. 2012: Steppes of Kazakhstan: diversity and present state. In: Marinus, J. A. Werger, M. \& van Staalduinen, A. (eds.) Eurasian steppes. Ecological problems and livelihoods in a changing world. Springer, Dordrecht, pp. 103-148.

Riecken, U., Finck, P., Raths, U., Schröder, E. \& Ssymank, A. 2006: Rote Liste der gefährdeten Biotoptypen Deutschlands. Zweite fortgeschriebene Fassung 2006. Naturschutz und Biologische Vielfalt 34: 1-318.

Rodwell, J. S., Schaminee, J. H. J., Mucina, L., Pignatti, S., Dring, J. \& Moss, D. 2002: The diversity of European Vegetation. An overview of phytosociological alliances and their relationships to EUNIS habitats. National Reference Centre for Agriculture, Nature and Fisheries, Wageningen, $168 \mathrm{pp}$.

Shelyag-Sosonko Y. R. (ed.) 1987: Green Book of Ukrainian SSR: Rare, endangered and typical of endangered plant communities. Nauk. Dumka, Kiev, 216 pp.

Siberian Academy of Sciences (ed.) 1996: Green Book of Siberia. Rare and in need of protection plant communities [in Russian]. Nauka, Novosibirsk, 396 pp.

Standing Committee to the Bern Convention (ed.) 2011: Convention on the Conservation of European Wildlife and Natural Habitats. Revised Annex I of Resolution 6 (1998). Council of Europe, Strasbourg.

Stoyko, S. M. 1983: Ecological basis of rare, unique and typical plant communities [in Russian]. Botanical Journal 68: 1574-1583.

Velásqueza, E., Fonteb, S. J., Barotc, S., Grimaldic, M., Desjardinsc, T. \& Lavelle P. 2012: Soil macrofauna-mediated impacts of plant species composition on soil functioning in Amazonian pastures. Applied Soil Ecology 56: 43-50.

Received: 25. 2. 2013 Accepted: 9. 4. 2014 Co-ordinating editor: Rosario G. Gavilán 